Portland State University

PDXScholar

\title{
Scientifically Defensible Fish Conservation and Recovery Plans: Addressing Diffuse Threats and Developing Rigorous Adaptive Management Plans
}

\author{
Kathleen G. Maas-Hebner \\ Oregon State University \\ Carl B. Schreck \\ US Geological Survey \\ Robert M. Hughes \\ Oregon State University \\ J. Alan Yeakley \\ Portland State University, yeakley@pdx.edu \\ Nancy Molina \\ Cascadia Ecosystems \\ Follow this and additional works at: https://pdxscholar.library.pdx.edu/esm_fac \\ Part of the Aquaculture and Fisheries Commons, and the Environmental Sciences Commons \\ Let us know how access to this document benefits you.
}

\section{Citation Details}

Kathleen G. Maas-Hebner, Carl Schreck, Robert M. Hughes, J. Alan Yeakley \& Nancy Molina (2016)

Scientifically Defensible Fish Conservation and Recovery Plans: Addressing Diffuse Threats and Developing Rigorous Adaptive Management Plans, Fisheries, 41:6, 276-285, DOI: 10.1080/ 03632415.2016 .1175346

This Article is brought to you for free and open access. It has been accepted for inclusion in Environmental Science and Management Faculty Publications and Presentations by an authorized administrator of PDXScholar. Please contact us if we can make this document more accessible: pdxscholar@pdx.edu. 


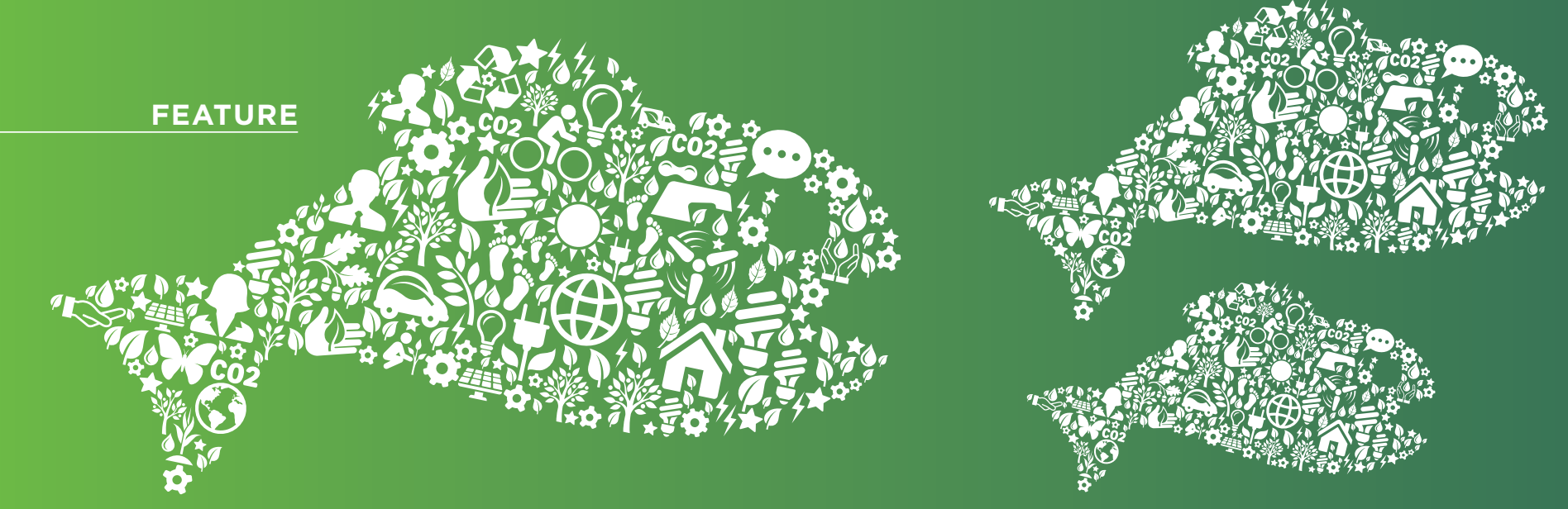

\section{Scientifically \\ Defensible Fish \\ Conservation and

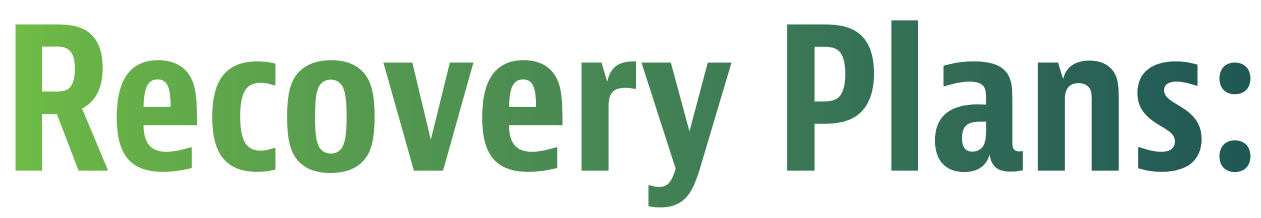

Addressing Diffuse Threats and Developing Rigorous Adaptive Management Plans



Carl Schreck

Robert M. Hughes

Amnis Opes Institute and Department of Fisheries \& Wildlife, Oregon State University, Corvallis, OR

\section{J. Alan Yeakley}

Department of Environmental Science \& Management, Portland State University, Portland, OR

\section{Nancy Molina}

Cascadia Ecosystems, Gresham, OR

Current address for Kathleen G. Maas-Hebner: 305 S. 9th St., Monroe, OR 97456.

Department of Fisheries \& Wildlife, Oregon State University, Corvallis, OR 97331. E-mail: KGMaasHebner@gmail.com

U.S. Geological Survey, Oregon Cooperative Fish \& Wildlife Research Unit, Oregon State University, Corvallis, OR 


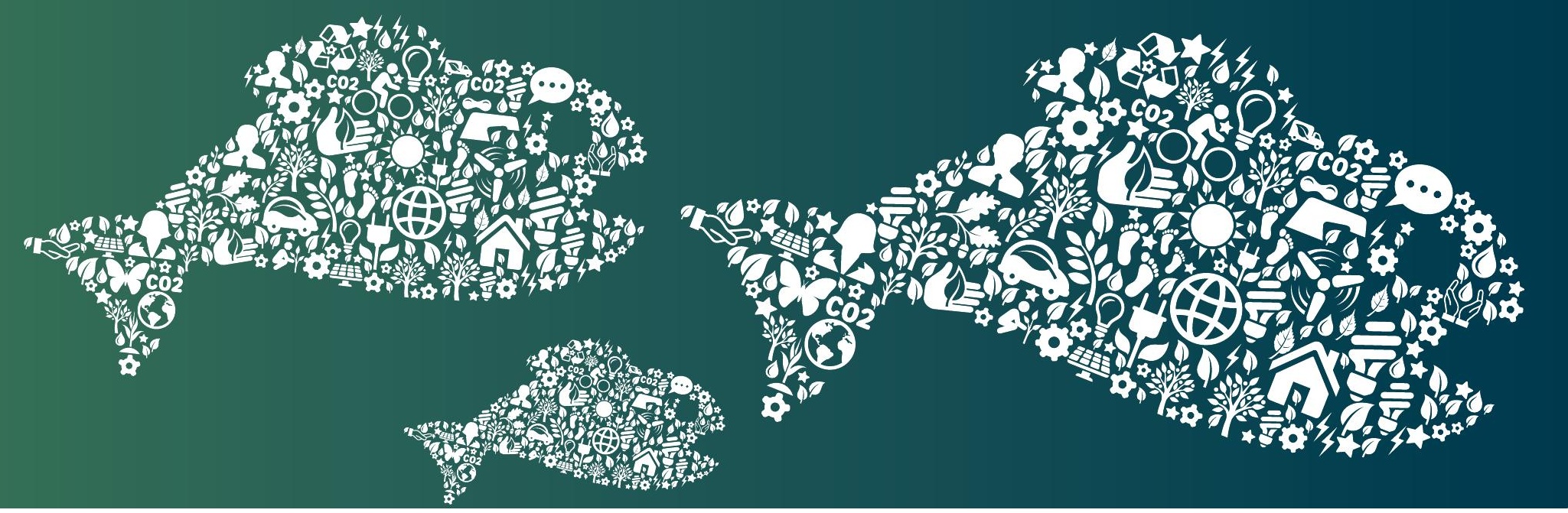

We discuss the importance of addressing diffuse threats to long-term species and habitat viability in fish conservation and recovery planning. In the Pacific Northwest, USA, salmonid management plans have typically focused on degraded freshwater habitat, dams, fish passage, harvest rates, and hatchery releases. However, such plans inadequately address threats related to human population and economic growth, intra- and interspecific competition, and changes in climate, ocean, and estuarine conditions. Based on reviews conducted on eight conservation and/or recovery plans, we found that though threats resulting from such changes are difficult to model and/or predict, they are especially important for wide-ranging diadromous species. Adaptive management is also a critical but often inadequately constructed component of those plans. Adaptive management should be designed to respond to evolving knowledge about the fish and their supporting ecosystems; if done properly, it should help improve conservation efforts by decreasing uncertainty regarding known and diffuse threats. We conclude with a general call for environmental managers and planners to reinvigorate the adaptive management process in future management plans, including more explicitly identifying critical uncertainties, implementing monitoring programs to reduce those uncertainties, and explicitly stating what management actions will occur when pre-identified trigger points are reached.

\section{Planes científicamente defendibles de conservación y recuperación de peces: Tratamiento de amenazas extendidas y desarrollo de planes rigurosos de manejo adaptativo}

Se discute la importancia de incorporar amenazas extendidas a la viabilidad de largo plazo de especies y hábitats para planear esfuerzos de conservación y recuperación. En el Pacífico noroeste de los EE.UU., los planes de manejo de salmónidos comúnmente se han enfocado en hábitats degradados de agua dulce, presas, pasajes para peces, tasas de cosecha y liberación de individuos cultivados. No obstante, dichos planes no abordan adecuadamente las amenazas relacionadas con la población humana y el crecimiento económico, la competencia intra e interespecífica, cambios en el clima ni las condiciones oceánicas o estuarinas. Sobre la base de una revisión llevada a cabo en ocho planes de conservación y/o recuperación, encontramos que pese a que las amenazas que se derivan de estos cambios son difíciles de modelar y/o predecir, éstas resultan ser particularmente importantes para especies diádromas de amplia distribución. Dentro de los planes se encontró que el manejo adaptativo es, asimismo, un componente crítico pero frecuentemente mal diseñado. Este tipo de manejo debe concebirse para responder a la evolución del conocimiento acerca de los peces y los ecosistemas que habitan; si se lleva a cabo adecuadamente, debiera mejorar los esfuerzos de conservación, reduciendo la incertidumbre proveniente de las amenazas conocidas y extendidas. Se concluye llamando la atención de gestores y planificadores ambientales para vigorizar el proceso del manejo adaptativo cuando se hagan planes de manejo en el futuro, que incluyan la identificación explícita de incertidumbres críticas, implementación de programas de monitoreo para reducir dichas incertidumbres y la definición explícita de las acciones de manejo que deben tomarse cuando se alcancen niveles críticos que hayan sido previamente identificados.

\section{Protection du poisson et plans de rétablissement scientifiquement défendables: Protection contre les menaces diffuses et développement rigoureux de plans de gestion adaptative} Nous discutons de l'importance de faire face aux menaces diffuses qui pèsent sur les espèces à long terme et la viabilité de l'habitat dans la conservation du poisson et la planification du rétablissement. Dans le Nord-Ouest Pacifique, aux ÉtatsUnis, les plans de gestion des salmonidés ont généralement porté sur l'habitat dégradé d'eau douce, les barrages, le passage des poissons, les taux de capture et les lâchers. Cependant, ces plans s'attaquent mal aux menaces liées à la population humaine et la croissance économique, la concurrence intra et interspécifique, et les changements des conditions climatiques, de l'océan, et des estuaires. D'après les analyses effectuées sur huit plans de conservation et/ou de rétablissement, nous avons constaté que même si les menaces résultant de ces changements sont difficiles à modéliser et/ou à prévoir, elles sont particulièrement importantes pour un grand nombre d'espèces diadromes. La gestion adaptative est également un élément essentiel, mais souvent mal élaboré de ces plans. La gestion adaptative devrait être conçue pour répondre à l'évolution des connaissances sur les poissons et leurs écosystèmes associés; si elle est faite correctement, elle devrait contribuer à améliorer les efforts de conservation en diminuant l'incertitude concernant les menaces connues et diffuses. Nous concluons par un appel général aux gestionnaires et planificateurs environnementaux pour relancer le processus de gestion adaptative dans les plans de gestion futurs, y compris à identifier plus explicitement les incertitudes critiques, la mise en œuvre des programmes de surveillance pour réduire ces incertitudes, et en indiquant explicitement les mesures de gestion qui seront mises en œuvre lorsque les seuils de déclenchement préidentifiés seront atteints. 
Fish conservation and recovery plans are prepared for species or populations of concern, or at risk of extinction. Plans typically assess current and desired species/population status and identify major threats, specific actions, measurable criteria for progress toward goals, and estimated costs to implement the plans. In 1997, Oregon instituted the Oregon Plan for Salmon and Watersheds (OCSRI 1997) to take an integrative approach by involving multiple state agencies and local watershed councils to manage watersheds, wild salmonids, and their habitats. A hallmark of the plan was the establishment of an independent science review board, the Independent Multidisciplinary Science Team (IMST). Since then, several salmonid evolutionarily significant units (ESUs) and distinct population segments have been listed as threatened or endangered under the federal Endangered Species Act of 1973 (ESA), requiring federal recovery plans throughout the Pacific Northwest, USA. Federal recovery plans were cooperatively prepared by the National Marine Fisheries Service (NMFS) and state agencies. Additionally, the Oregon Department of Fish and Wildlife (ODFW) is required to prepare fish conservation plans at the state level to meet the legal requirements of Oregon's Native Fish Conservation Policy (Oregon Administrative Rule 635-007-0502).

During its tenure, IMST reviewed seven ODFW recovery and/or conservation plans prepared for Pacific salmon Oncorhynchus spp. and steelhead (anadromous Rainbow Trout O. mykiss), and one conservation plan for White Sturgeon Acipenser transmontanus. In general, IMST found ODFW's efforts in fish conservation and recovery planning to be progressive, scientifically sound, and based on strong monitoring programs. Nonetheless, frequent discussions between ODFW and IMST identified several challenges for increasing the scientific validity of each plan. In this article, we address several diffuse threats that arose through those discussions. We believe that those threats pose significant risks to critical fish populations worldwide and may be overlooked or poorly addressed in management plans. In addition, we present how adaptive management, if used properly, could alleviate issues related to such threats and scientific uncertainty. Although the IMST's experience with conservation and recovery plans was centered on anadromous species in Oregon, the key issues addressed here apply widely to other fish populations, particularly diadromous species with large ranges supporting commercial and/or recreational fisheries.

\section{DIFFUSE THREATS}

The Columbia River basin has a long history of commercial harvest, fish hatchery production and release, and hydroelectric dams (Lichatowich 1999). Because of this history, Columbia and Snake River basin salmonid management schemes are firmly centered in the "four H's" or "all H's" approach (i.e., hydropower and other dams, harvest, hatcheries, and freshwater habitat). This approach is aimed at "improving conditions in many life stages, freshwater spawning and rearing, juvenile migration, ocean transition, and upstream migration" (Federal Caucus 2000:2) and is integrated into the region's subbasin plans, federal biological opinions, and recovery plans. The four $\mathrm{H}$ objectives were considered to be the most risk-averse approach to achieving recovery of threatened and endangered Pacific salmon and steelhead (Federal Caucus 2000; Hoekstra et al. 2007). Such an approach, however, tends to omit information about the risks associated with human population growth and natural resource use that lead to expansion of industrial, mineral and fossil fuel extraction, and urban and residential areas across the landscape; intra- and interspecies competition with hatchery-origin fish resulting from introductions; climate change, including both warming effects and precipitation pattern and storm intensity changes; and changing ocean/estuarine conditions.

We define diffuse threats as environmental conditions potentially affecting population and species viability that have experienced significant changes in incidence, intensity, or distribution, or are newly recognized phenomena. In this section, we discuss four large-scale diffuse threats (land use patterns, climate change, changing ocean/estuarine conditions, and marine intraspecific and freshwater intra- and interspecific competition) that we feel are likely to affect fish species globally. We acknowledge that other threats exist that are centered only at local and regional levels, and those should be addressed as appropriate.

\section{CHANGING LAND USE PATTERNS}

Human population and economic growth drive local and regional land use patterns and conversion of native ecosystems to managed systems. Increasing demands by growing human populations for water, energy sources, minerals, timber, agricultural lands, and buildable lands will continuously compete with the management and conservation of aquatic habitats. Such changes affect various ecosystem characteristics, including streamflow, hydrological connectivity and fish passage barriers, water quality (e.g., temperature, turbidity, anthropogenic toxic chemicals, and sediment loads), instream physical habitat quality, invasive nonnative species, and aquatic biota composition (Yeakley et al. 2014). In Oregon, land use regulations aim to protect agricultural and forest lands from widespread development (Molina 2014). Nevertheless, human population growth inevitably leads to conversion of native ecosystems and natural resource lands (e.g., agriculture and timber) to urban, rural residential, and industrial lands. Those conversions increase negative impacts on watershed functions and aquatic ecosystems (Maas-Hebner and Dunham 2014), particularly through increased stormwater runoff (Yeakley 2014) and habitat loss (Hughes et al. 2014). Although many fisheries biologists focus on improving local instream and riparian habitat conditions, research has indicated that catchment land use explains more (Roth et al. 1996; Marzin et al. 2012), or considerable amounts (Wang et al. 2003; Sály et al. 2011; Macedo et al. 2014), of the variability in aquatic biota. Tedesco et al. (2013) and Oberdorff et al. (2015) estimated that land and water use pressures accounted for more fish biodiversity losses than did climate change globally and in the Amazon River basin, respectively.

To address population growth and climate change in recent plans, ODFW (2010; ODFW and NMFS 2011) incorporated a $20 \%$ increase in their abundance goal for each conservation gap (i.e., difference between a population's current status and the target status). By setting the ultimate abundance goal $20 \%$ higher than what would otherwise be considered success for a program, the information needs and corrective actions are accelerated or amplified. Those higher goals indirectly compensate for the unquantified effects of population growth and climate change that may make that higher goal difficult to attain yet still meet a more achievable lower goal. This is a temporary and indirect approach being used by ODFW to address both human population growth and climate change 
impacts in model scenarios using an approach the agency developed called "scenario analysis." The information and data needs were then integrated into ODFW's monitoring, research, and evaluation plans. Once ODFW is able to determine more accurate estimates of human population growth and climate change impacts, the scenario goals (e.g., abundance) in the plans can then be adjusted.

Alternative futures analysis (also known as "futuring" or "scenario planning") also could be used to predict potential local and regional changes in watersheds over time in response to changes in human demographics and land use patterns (Hulse et al. 2004). Alternative futures analysis is a spatially explicit modeling approach that can be used to predict future land use patterns across landscapes, and the likely effects that land use policies and actions will have on watershed functions (e.g., increased stormwater runoff and erosion, water quality impairment) and stream ecosystems (e.g., loss of riparian cover, channel straightening, and increased road crossings and migration barriers; Molina 2014). The process includes characterizing current and historical landscapes within the geographic area of concern and the present trajectory of landscape change (Baker et al. 2004; Hulse et al. 2004). Those landscapes then are compared with alternative scenarios (e.g., increased rate of urban and rural residential sprawl, increased resource extraction, conservation). Analysts then are able to evaluate how altered land use patterns within a watershed or management area may affect aquatic ecosystems and riparian area conditions.

There are several examples of the use of alternative futuring analysis in the United States. In Oregon, researchers modeled alternative futures for the Willamette Valley under current land use regulations, increased development rates under relaxed regulations, and decreased development under conservationminded regulations (Baker et al. 2004). Resource endpoints examined included water allocation (Dole and Niemi 2004), main-stem river and channel changes (Gregory et al. 2002), and stream ecosystem conditions (Van Sickle et al. 2004). Increased conservation planning was estimated to recover aquatic and terrestrial indicators by $20-70 \%$, compared to losses incurred since Euro-American settlement. Increased development rates were projected to have little effect on aquatic biota because of the current dominance of agriculture where development would occur and where habitat is already poor (Baker et al. 2004). Lohse et al. (2008) modeled future land use change (conversion of land to rural residential homes and increased acreage in vineyards) in the Russian River Basin in California and the potential effects on high-quality salmon spawning habitat. They concluded that rural-residential and vineyard development would decrease spawning habitat more than urban development because more land would be converted to the former than to urban, and because forecasted urban development would occur in agricultural watersheds that currently have poor spawning habitat. Wenger et al. (2010) forecasted the effects of alternative land management polices (i.e., development under current regulation versus development under a federal ESA habitat conservation plan) on three freshwater fish species in Georgia. Their forecasts indicated that the sensitive Etowah Darter Etheostoma etowahae was likely to decline by $84 \%$ in the absence of a habitat conservation plan, but by $23 \%$ if a plan was implemented.

\section{CLIMATE CHANGE}

In the Pacific Northwest USA and western Canada, global warming is expected to shift precipitation from snow to rain at higher altitudes (ISAB 2007; Healey 2011; Mote et al. 2014). In turn, late-fall and winter stream flows likely will increase, as will the intensity and frequency of floods. Diminished annual snow packs will reduce late-summer and early fall streamflows, thereby allowing stream temperatures to rise. Basins providing suitable freshwater salmonid habitat at the beginning of the 20th century may become unsuitable in the future (Lassalle et al. 2008). In the Arctic, warming is expected to decrease ice cover and open more streams for colonization by salmonid species forced northward seeking suitable freshwater habitats (Healey 2011). Deleterious changes will not be restricted to freshwater environments (Doney et al. 2014). Abdul-Aziz et al. (2011) predict that thermal habitats in the open ocean will also be affected by warming, and by the year 2100 , summer habitat for salmonids in southern latitudes in the North Pacific Ocean and portions of the southern Arctic Ocean could decrease significantly. Healey (2011) and Nielsen et al. (2013), however, reported that populations of both Atlantic Salmon Salmo salar and Pacific salmon are expanding into Arctic-drainage rivers. In general, salmonid mortality rates are predicted to increase because of temperature-mediated bioenergetic effects on embryonic development, growth, smolt migration, predation by coolwater predators, and increased rates of disease and parasitism on both juveniles and adults (Scheuerell and Williams 2005; ISAB 2007; Martins et al. 2011). In addition, the cumulative effects of climate change may have considerable long-term effects on life cycles, affecting successive life stages across generations (Healey 2011).

As we mentioned earlier, ODFW added a $20 \%$ conservation buffer into analyses it used for two recovery plans as temporary measures until more information is gained on population impacts from changing human demographics and climate. Although $20 \%$ may be a sound choice, lumping both climate change and human demographics together is not. Climate change tends to pose a region-wide threat with intensity varying somewhat by location, whereas human demographic and land use changes are localized. Fish species' responses to climate change may include altered distributions in time and space, changes in productivity, and adaptation to new conditions (Kingsolver 2009), or increased rates of hybridization with nonnative species (Muhlfeld et al. 2014). These responses are exacerbated by local land use changes. Therefore, an attempt should be made to determine whether this across-the-board approach is adequate for each population being assessed and which populations are at greatest risk. For fall Chinook Salmon O. tshawytscha, ODFW (2013) incorporated local climate change modeling results from Doppelt et al. (2008) for the Rogue River Basin. Those modeling results indicated that increased summer air temperatures significantly decreased snowpack and summer streamflows, but the models did not incorporate increased levels of urbanization or rural residential development in the basin and their effects on flows. Those future changes could be assessed through alternative futures analysis.

The ability to model potential climate change effects on fish populations is steadily increasing, and several broadscale assessments have been reviewed by others (e.g., Hobday and Evans 2013; Hollowed et al. 2013a, 2013b; Punt et al. 2014). Lassalle et al. (2008) constructed predictive distribution models for several diadromous fish species in Europe, North Africa, and 
the Middle East based on biogeographical patterns of freshwater fish, which provided environmental information affecting distribution. Using one or two climatic variables for each model, they were able to create predictive models for 21 of 28 species to determine likely changes in distribution in response to the changing climate.

Based on projected changes to watersheds from climate change, it also may be possible to use alternative futures analysis and predictive modeling to predict which streams and water bodies may be most altered during the planning horizon. This analysis is needed because regional climate change models are too coarse for estimating what will happen where fish are at key periods of their life cycles. The particular microclimates of spawning, rearing, and migration reaches determine growth and mortality rates and population success or extirpation, in particular the thermal conditions and forage base when the fish are present. For example, Felipe et al. (2013) used generalized linear models, generalized additive models, random forest, and multivariate adaptive regression to build predictive species distribution models for the 2080s based on the Alb emissions scenario and habitat conditions. They found that climate was a better predictor than stream topography or land cover and predicted that the distribution of Brown Trout Salmo trutta across their Europe-wide sampling sites would be reduced by $64 \%$ by 2080 . Isaak et al. (2010) used changes in stream temperatures from 1993 to 2006 to estimate $11 \%$ to $20 \%$ losses in specific headwater habitats for Bull Trout Salvelinus confluentus in the Boise River Basin, Idaho.

\section{CHANGES IN THE MARINE ENVIRONMENT}

Ocean cycles, such as the Pacific decadal oscillations and El Niño events (Salinger 2013), and modified environmental conditions, including altered surface water temperatures, altered estuarine habitat (Jones et al. 2014), acidification (decrease in surface water pH; Raven et al. 2005; Orr et al. 2009), and hypoxic zones (areas of depleted dissolved oxygen; Ekau et al. 2010; Zhang et al. 2010), may significantly alter marine carrying capacity, species productivities, and predator-prey relationships. These changes will affect the ocean-inhabiting life stages of anadromous species for which conservation and recovery plans are written. These and other phenomena can have unexpected or poorly predicted effects on marine/estuarine life and food webs (e.g., Feely et al. 2010; Kaeriyama et al. 2012; Brander 2013; Busch et al. 2013). Coastal and estuarine systems, as well as inland seas, vary in their vulnerability to these changes, depending on their geophysical settings; species in these areas may experience more deleterious effects than pelagic species. Different species and populations are expected to respond differently to changing ocean and estuarine conditions because of their differing migration routes, life histories, and ocean rearing environments. For example, yearling Coho Salmon $O$. kisutch and yearling and subyearling Chinook Salmon from the Columbia River differ in their distributions along the Oregon and Washington coasts, and catches were lowest when spring ocean temperatures were high and highest when temperatures were low (Peterson et al. 2014). When Pacific Hake (also known as Pacific Whiting) Merluccius productus (a key juvenile salmon marine predator) are common (during warm years) and other forage fish abundance, turbidity, and Columbia River discharges are low, salmon survival is low. If any of those latter variables is high, salmon survival is high (Peterson et al. 2014). Depending on the species, Pacific salmon and steelhead may spend 1 to 5 years in the ocean (Groot and Margolis 1991; Augerot 2005), and Atlantic Salmon may spend 1 to 4 years in the ocean (Jonsson and Jonsson 2011). Some Chinook Salmon and Coho Salmon spend weeks to months in estuaries (Reimers 1973; Jones et al. 2014). This variability in both marine/estuarine conditions and species responses suggests some inherent dangers in treating oceans and estuaries in the same way for all fish populations and species - or largely ignoring them in conservation and recovery plans for diadromous species.

Pacific decadal oscillations and El Niño cycles are frequently incorporated into ODFW life cycle modeling for salmonids (ODFW 2010; ODFW and NMFS 2011), but the information available to predict population level changes as a result of less cyclic phenomena such as hypoxia and acidification is currently nonexistent. Dorner et al. (2013) cautioned that until there is better understanding of salmon productivity and climate-driven oceanographic conditions, adjusting stock assessment models (which do well for near-term predictions) to reflect future climate scenarios is likely to lead to poor management options. Therefore, taking a precautionary approach is warranted. In the short term, this may be as simple as identifying vulnerable fish species and adding an additional $10 \%$ to $20 \%$ conservation buffer for abundance goals into modeling as ODFW (2010; ODFW and NMFS 2011) did for climate change and human population demographics, and then determining what data and monitoring are needed over the long term to better assess those impacts. Research, monitoring, and evaluation plans need to be developed for vulnerable species and populations and integrated into an adaptive management framework (discussed later in the article).

\section{MARINE ECOSYSTEM INTRASPECIFIC COMPETITION}

Artificial propagation is used in many regions to support commercial and recreational fisheries. Hatchery-produced salmonids migrate to the sea with naturally produced, wild salmonids. In the salmonid plans IMST has reviewed, potential negative effects of hatchery fish on wild populations have focused on genetic effects, straying and spawning in freshwater systems, behavioral interactions in early freshwater life stages and on spawning grounds, and incidental harvest/bycatch of wild fish when hatchery fish are targeted. However, hatchery and wild fish spend the same amount of time growing, maturing, and competing for resources in marine and estuarine environments and can be highly sympatric (e.g., Chinook Salmon; Daly et al. 2012). Marine carrying capacity may also decrease suitable habitat for some species as surface water temperatures increase (e.g., Chum Salmon O. keta; Kaeriyama et al. 2012). Ruggerone et al. (2012) found evidence of density-dependent ocean growth and survival of Chum Salmon in the North Pacific Ocean. Kaeriyama et al. (2012) found density-dependent growth and survival for Chum Salmon, Pink Salmon O. gorbuscha, and Sockeye Salmon O. nerka. Their findings indicate the potential for intraspecific competition between hatchery and wild salmon when hatchery fish are released to provide for increased harvest levels.

The existence of density-dependent relationships for salmon in the marine environment is a recent finding. Stock-recruitment models that assume density-independent relationships in the marine environment should be revaluated by running scenarios with the assumption that relationships are density dependent. Populations that may be at greatest risk for intraspecific 
competition should be identified and evaluated to determine whether additional conservation buffers are needed and to assess what data needs exist. As with many marine issues, most state and provincial resource agencies do not have the capacity to monitor resources at sea; therefore, we encourage those agencies to work with federal/territorial agencies, universities, and other research groups to identify critical data needs that large-scale, multi-institutional research and monitoring can address.

\section{FRESHWATER ECOSYSTEM INTRASPECIFIC AND INTERSPECIFIC COMPETITION}

The ODFW and other fisheries managers face a dilemma in trying to rehabilitate wild salmon and steelhead populations, many of them listed under the Endangered Species Act, while trying to provide consistent harvest opportunities by rearing and releasing hatchery fish. This is a difficult balancing act because of the clear contradiction between maintaining or increasing hatchery production to sustain near-term harvest and decreasing that production to reduce genetic, competitive, and other risks to wild populations. For example, improved understanding of the genetic consequences of hatchery fish straying to spawning grounds (e.g., Ford 2002; Araki et al. 2007, 2008) and of the potential for hatchery-origin salmonids to have ecological effects on their wild counterparts (e.g., Kostow and Zhou 2006; Buhle et al. 2009; Naman and Sharpe 2012; Tatara and Berejikian 2012; Carmichael et al. 2015) has clarified the need for substantial changes in hatchery programs to conserve wild fish.

Fisheries managers have responded by changing hatchery broodstocks, improving hatchery practices within facilities, shifting some hatchery releases to areas where terminal fisheries encounter few at-risk salmon, and attempting to better control natural spawning by hatchery-origin fish. With the exception of Oregon coast and lower Columbia River Coho Salmon populations, however, the region's fishery managers have generally chosen to avoid the most obvious source of impactsaggregate hatchery output - to reduce risks to wild anadromous salmonids (Paquet et al. 2011; NMFS 2014; ODFW 2014). The ODFW (2014) has proposed establishing refuge areas where hatchery programs are excluded as a way to protect selected wild populations from risks posed by continued large releases of hatchery fish, at least within the freshwater environment. There may be difficulties in applying this approach given that (1) hatchery-origin spawners stray into refuges from large programs outside their boundaries, and (2) resistance to refuge designation is strong when in conflict with existing hatchery programs, even in areas previously identified as being of high priority for conserving wild salmon.

In addition to wild salmon, there are serious concerns with native trout and char. For example, endemic Cutthroat Trout $O$. clarkii subspecies in streams often are outcompeted by nonnative Brown Trout, Brook Trout Salvelinus fontinalis, and Rainbow Trout $O$. mykiss; the latter also hybridizes with Cutthroat Trout (Allendorf and Leary 1988; Muhlfeld et al. 2014). In western U.S. oligotrophic lakes, native Cutthroat Trout are outcompeted by nonnative Lake Trout ( $S$. namaycush; Martinez et al. 2009). Fishery agencies have worked to eliminate hatchery and other nonnative fish by ceasing stocking altogether, stocking sterile fish, poisoning, electrofishing, gill netting, liberalizing catch regulations on the nonnatives, and erecting migration barriers - but those barriers eliminate adfluvial life histories (Martinez et al. 2009). Native Cutthroat Trout populations also can be supplemented temporarily with hatchery fish, and habitat improvements can be implemented to increase survival rates of native fish, but there are serious limitations to both approaches. Supplementation can result in genetic and ecological alterations as with salmon (discussed above), and local habitat improvements are expensive and limited by watershed degradation (Roni et al. 2008; Beechie et al. 2010).

Another form of intra- and interspecies interaction is the role that salmon play as keystone species in marine and aquatic ecosystems. Throughout the North Pacific range of salmon, salmon carcasses have been reported to be important sources of nutrients for juvenile and resident salmonids (Bilby et al. 1998; Cedarholm et al. 1999; Wipfli et al. 2003), aquatic macroinvertebrates (Cedarholm et al. 1999; Quamme and Slaney 2003), terrestrial predators (Cedarholm et al. 1999; Hilderbrand et al. 1999; Darimont and Reimchen 2002), and riparian vegetation (Bartz and Naiman 2005; Nagasaka et al. 2006). Marine salmon are important food sources for endangered orcas Ocrinus orca (Nichol and Shackleton 1996), and salmon prey on forage fish that are commercially harvested. Instead of a single fish or fishery focus, wise ecosystem management or ecological salmon management would consider these food web connections in setting salmon and forage fish harvest levels (Michael 1998; Cedarholm et al. 1999). However, that would mean reduced commercial and recreational catch levels (Cedarholm et al. 1999; Stockner 2003; Piccolo et al. 2009), and thus a full accounting of ecosystem services in these river ecosystems is likely required to achieve sustainable management outcomes (Yeakley et al. 2016).

\section{ADAPTIVE MANAGEMENT IN CONSERVATION} AND RECOVERY PLANS

Adaptive management is a crucial but often poorly written component of conservation and recovery plans, and typical adaptive management plans omit research on land use changes, intra- and interspecific competition, climate change, and changing ocean and estuarine habitat conditions. First described by Holling (1978), adaptive management uses either a rigorous decision-making process (Conroy and Peterson 2013) or a deliberately experimental approach (Walters 1986) to increase knowledge and to decrease uncertainty associated with management outcomes. Both approaches are grounded by the need for rigorous monitoring. The history and requirements of adaptive management (Rist et al. 2012), its pros and cons (Parma et al. 1998), implementation impediments (Benson and Stone 2013), and plan effectiveness (Nie and Schultz 2012) have been reviewed by others. Those authors concede that adaptive management has become an agency buzzword and its concepts are frequently simplified to the point that management plans are no more than ad hoc trial-and-error approaches versus deliberate, predetermined, and monitored actions that will improve management of the resource over time. By definition, adaptive management is a structured decision-making process for recurrent management decisions made under uncertainty (Runge 2011). Therefore, adaptive management should (1) explicitly identify existing knowledge and critical uncertainties, (2) clearly articulate management expectations, (3) design and implement targeted monitoring programs aimed at gaining knowledge related to the critical uncertainties identified, (4) update predictive models based on ongoing monitoring information, and (5) adjust future management decisions based on new knowledge about the resource being managed (Runge 
2011). Within this framework, plans must also explicitly state what will and will not occur when pre-identified trigger points for decision making are reached.

Monitoring designed to reduce critical uncertainties will not only help agencies and society overcome knowledge gaps but will also lead to more efficient uses of scarce monitoring resources, funding, and staff time because only monitoring that will help improve long-term management will be emphasized. Harvey et al. (2002) found that 61 federal ESA plan revisions for vertebrates, invertebrates, and plants had incorporated more adaptive management provisions in monitoring protocols.

Nonetheless, Nie and Schultz (2012) found that several adaptive management plans they reviewed lacked monitoring plans designed as hypothesis-driven experiments with replicates and controls aimed at increasing knowledge of the ecosystem being managed. Such plans may not decrease uncertainty and improve management over time. Nie and Schultz (2012) also found that trigger points for decision making were often no more than vague statements, rather than conditions leading to specific actions and timelines indicating exactly what should occur when predetermined trigger points were reached. Improved management can be accomplished only if the new information is used to reassess management options, reevaluate uncertainty, and modify future management decisions as appropriate. These future management decisions are then monitored and the cycle continues. This does not mean that all monitoring should be hypothesis based or incorporate replicates and controls. For example, long-term, standardized spawner counts (Steel et al. 2012), population monitoring (Dudley et al. 2015), temperature and discharge monitoring (Dudley et al. 2015), and regional pattern studies (USEPA 2013) are very useful for obtaining status and trend data.

As noted above, few sound adaptive management plans have been available in the past. Using guidance from the NMFS (2007), ODFW provided fairly extensive monitoring and adaptive management plans in three of its final joint conservation and recovery plans (ODFW 2010; ODFW and NMFS 2011). It is too early in the process to determine how effective the adaptive management plans will be, but those ODFW plans and NMFS (2007) can serve as a starting point for other planners. Additionally, Conroy and Peterson (2013) recommended using the U.S. Department of Interior's adaptive management protocol (Williams et al. 2009) as a model. Allen and Gunderson (2011) identified nine general sources of failure in adaptive management plans that planners also can use while developing and implementing plans.

\section{SUMMARY}

To strengthen the scientific credibility of conservation and recovery plans, it is important for planners to fully consider, and incorporate in their assessments, those diffuse threats that will likely influence long-term outcomes for the species or populations being managed. We defined diffuse threats as environmental conditions potentially affecting fish population and species viability that have changed in incidence, intensity, or distribution or are newly recognized phenomena. We chose to focus on five threats that are global concerns: (1) human population and economic growth, (2) changes in climate, (3) changes in ocean and estuarine conditions, (4) intraspecific competition in the marine environment, and (5) intra- and interspecific competition in freshwater ecosystems.
Human and economic growth compete with conservation and management efforts in watershed and aquatic ecosystems by placing more demands on buildable lands and natural resource extraction. Modeling tools such as alternative futures analysis can be used to predict land use impacts under various management scenarios. Climate change affects all aquatic ecosystems (marine, estuarine, and freshwater). Global and regional models are being constructed to predict changes in some fish populations in response to precipitation patterns, changes in streamflow, and terrestrial and marine temperatures. In the absence of such models for specific fish species, it will be important to add some type of conservation buffer into management goals to allow for short- and long-term changes in climate conditions. As with climate, we are now aware that the marine environment is changing (i.e., hypoxia, acidification, and altered surface water temperatures). Data are lacking for modelers to construct relatively accurate prediction models, so fish managers should consider using a precautionary approach and work with researchers to fill in data gaps. Intraspecific competition in the marine environment is now being recognized in Pacific salmon populations. As with changes in the marine environment, data are lacking on how much competition is occurring and what the impacts are to salmon stocks. Fish managers should work with researchers to obtain better data to assess the overall impact interspecific competition may have on stocks. Finally, intra- and interspecific competition is occurring in freshwater ecosystems and affecting all salmonid life stages. Concerns related to hatchery fish production have led to changes in hatchery rearing practices, release strategies, and targeted harvests. Control strategies have also been developed and implemented for nonnative species. Those efforts should be continually assessed for effectiveness.

Conservation and recovery plans are living documents and should be regularly reviewed and revised so that many diffuse threats that cannot be addressed completely in the near term can be over the long term. Rigorous and statistically sound research and monitoring programs are also critical and require significant cooperation between fish management agencies and research entities. Finally, we believe that well-designed and implemented adaptive management is critical to the long-term conservation and recovery of many fish species. However, it is an arduous process to develop and implement rigorous adaptive management plans. Such plans must explicitly identify critical uncertainties, implement monitoring programs to reduce those uncertainties, and explicitly state what management actions will occur when monitoring determines that preidentified trigger points are reached (Bouwes et al. 2016). Therefore, we encourage all management agencies to share their successes and, just as important, their failures in adaptive management in publications and at professional meetings.

\section{ACKNOWLEDGMENTS}

This article draws from the combined experience and opinions of current and past IMST members and scientific staff reviewing the scientific merits of draft fish recovery and conservation plans. The conclusions drawn here may not reflect opinions of past IMST members and staff and do not necessarily reflect the final recovery plans approved by the NMFS or conservation plans adopted by the Oregon Fish and Wildlife Commission. Insightful reviews of previous versions of this article were provided by Chuck Huntington, William Pearcy, Thomas Stahl, co-chief science editors Olaf Jensen and Jeff Schaeffer, and five anonymous reviewers. 
FUNDING

Funding for this article was provided by the Pacific Coastal Salmon Recovery Fund via the Oregon Watershed Enhancement Board to Oregon's Independent Multidisciplinary Science Team.

\section{REFERENCES}

Abdul-Aziz, O. I., N. J. Mantua, and K. W. Myers. 2011. Potential climate change impacts on thermal habitats of Pacific salmon (Oncorhynchus spp.) in the North Pacific Ocean and adjacent seas. Canadian Journal of Fisheries and Aquatic Sciences 68:16601680.

Allen, C. R., and L. H. Gunderson. 2011. Pathology and failure in the design and implementation of adaptive management. Journal of Environmental Management 92:1379-1384.

Allendorf, F. W., and R. F. Leary. 1988. Conservation and distribution of genetic variation in polytypic species, the Cutthroat Trout. Conservation Biology 2:170-184

Araki, H., B. A. Berejikian, M. J. Ford, and M. S. Blouin. 2008. Fitness of hatchery-reared salmonids in the wild. Evolutionary Applications 1:342-355.

Araki, H., B. Cooper, and M. S. Blouin. 2007. Genetic effects of captive breeding cause a rapid, cumulative fitness decline in the wild. Science 318:100-103.

Augerot, X. 2005. Atlas of Pacific salmon. University of California Press, Berkeley.

Baker, J. P., D. W. Hulse, S. V. Gregory, D. White, J. Van Sickle, P. A Berger, D. Dole, and N. H. Schumaker. 2004. Alternative futures for the Willamette River Basin, Oregon. Ecological Applications 14:313-324.

Bartz, K. K., and R. J. Naiman. 2005. Effects of salmon-borne nutrients on riparian soils and vegetation in southwest Alaska. Ecosystems 8:529-545.

Beechie, T. J., D. Sear, J. Olden, G. R. Pess, J. Buffington, H. Moir, P. Roni, and M. M. Pollock. 2010. Process-based principles for restoring river ecosystems. BioScience 60:209-222.

Benson, P. H., and A. B. Stone. 2013. Practitioner perceptions of adaptive management implementation in the United States. Ecology and Society [online].

Bilby, R., E., B. R. Fransen, P. A. Bisson, and J. W. Walter. 1998. Response of juvenile Coho Salmon (Oncorhynchus kisutch) and steelhead (Oncorhynchus mykiss) to the addition of salmon carcasses to two streams in southwestern Washington, U.S.A. Canadian Journal of Fisheries and Aquatic Sciences 55:1909-1918.

Bouwes, N., S. Bennett, and J. Wheaton. 2016. Adapting adaptive management for testing the effectiveness of stream restoration: an intensively monitored watershed example. Fisheries 41:84-91.

Brander, K. 2013. Climate and current anthropogenic impacts on fisheries. Climate Change 119:9-21.

Buhle, E. R., K. K. Holsman, M.D. Scheuerell, and A. Albaugh. 2009. Using an unplanned experiment to evaluate the effects of hatcheries and environmental variation on threatened populations of wild salmon. Biological Conservation 142:2449-2455.

Busch, D. S., C. J. Harvey, and P. McElhany. 2013. Potential impacts of ocean acidification on the Puget Sound food web. ICES Journal of Marine Science 70:823-833.

Carmichael, R. W., M. W. Chilcote, and C. W. Huntington. 2015. Comment: natural productivity in steelhead populations of natural and hatchery origin-assessing hatchery spawner influence. Transactions of the American Fisheries Society 144:1292-1297.

Cedarholm, C. J., M. D. Kunze, T. Murota, and A. Sibatani. 1999. Pacific salmon carcasses: essential contributions of nutrients and energy for aquatic and terrestrial ecosystems. Fisheries 24(10):6-15.

Conroy, M. J., and J. T. Peterson. 2013. Decision making in natural resource management: a structured, adaptive approach. Wiley, Hoboken, New Jersey.

Daly, E. A., R. D. Broduer, J. P. Fisher, L. A. Weitkamp, D. J. Teel, and B. R. Beckman. 2012. Spatial and trophic overlap of marked and unmarked Columbia River Basin spring Chinook Salmon during early marine residence with implications for competition between hatchery and naturally produced fish. Environmental Biology of Fishes 94:117-134.

Darimont, C. T., and T. E. Reimchen. 2002. Intra-hair stable isotope implies seasonal shift to salmon in gray wolf diet. Canadian Journal of Zoology 80:1638-1642.

Dole, D., and E. Niemi. 2004. Future water allocation and in-stream values in the Willamette River Basin: a basin-wide analysis. Ecological Applications 14:355-367.
Doney, S., A. A. Rosenburg, M. Alexander, F. Chavez, C. D. Harvell, G. Hoffman, M. Orback, and M. Ruckelshause. 2014. Oceans and marine resources. Pages 557-578 in J. M. Melillo, T. C. Richmond, and G. W. Yohe, editors. Climate change impacts in the United States: the third national climate assessment. U.S. Global Change Research Program, Washington, D.C.

Doppelt, B., H. Hamilton, C. D. Williams, and M. Koopman. 2008. Preparing for climate change in the Rogue River Basin of southwest Oregon. Institute for Sustainable Environment, University of Oregon, Eugene.

Dorner, B., K. R. Holt, R. M. Peterman, C. Jordan, D. P. Larsen, A. R. Olsen, and O. I. Abdul-Aziz. 2013. Evaluating alternative methods for monitoring and estimating responses of salmon productivity in the North Pacific to future climatic change and other processes: a simulation study. Fisheries Research 147:10-23.

Dudley, R. K., S. P. Platania, and G. C. White. 2015. Rio Grande Silver Minnow population monitoring program results from February to December 2014. Final report prepared for the Middle Rio Grande Endangered Species Collaborative Program. U.S. Bureau of Reclamation, Albuquerque, New Mexico.

Ekau, W., H. Auel, H.-O. Pörtner, and D. Gilbert. 2010. Impacts of hypoxia on the structure and processes in pelagic communities (zooplankton, macro-invertebrates and fish). Biogeosciences [online serial] 7:1669-1699.

Endangered Species Act of 1973. U.S. Code, volume 16, sections 1531-1544.

Federal Caucus. 2000. Conservation of Columbia Basin fish: draft basin-wide salmon recovery strategy (update of the all-H paper) July 27, 2000. Bonneville Power Administration, Portland, Oregon.

Feely, R. A., S. R. Alin, J. Newton, C. L. Sabine, M. Warner, A. Devol, C. Krembs, and C. Maloy. 2010. The combined effects of ocean acidification, mixing, and respiration on $\mathrm{pH}$ and carbonate saturation in an urbanized estuary. Estuarine, Coastal and Shelf Science 88:442-449.

Felipe, A. F., D. Markovic, F. Pletterbauer, C. Tisseuil, A. De Wever, S Schmutz, N. Bonada, and J. Freyhof. 2013. Forecasting fish distribution along stream networks: Brown Trout (Salmo trutta) in Europe. Diversity and Distributions 19:1059-1071.

Ford, M. J. 2002. Selection in captivity during supportive breeding may reduce fitness in the wild. Conservation Biology 16:815-825.

Gregory, S., L. Ashkenas, D. Oetter, R. Wildman, P. Minear, and K. Wildman. 2002. Mainstem river. Pages 112-113 in D. W. Hulse, S. V. Gregory, and J. P. Baker, editors. Willamette River Basin: trajectories of environmental and ecological change. Oregon State University Press, Corvallis.

Groot, C., and L. Margolis. 1991. Pacific salmon life histories. University of British Columbia Press, Vancouver.

Harvey, E., J. M. Hoekstra, R. J. O'Connor, and W. F. Fagan. 2002. Recovery plan revisions: progress or due process? Ecological Applications 12:682-689.

Healey, M. 2011. The cumulative impacts of climate change on Fraser River Sockeye Salmon (Oncorhynchus nerka) and implications for management. Canadian Journal of Fisheries and Aquatic Sciences 68:718-737.

Hilderbrand, G. V., C. C. Schwartz, C. T. Robbins, M. E. Jacoby, T. A Hanley, S. M. Arthur, and C. Servheen. 1999. The importance of meat, particularly salmon, to body size, population productivity, and conservation of North American brown bears. Canadian Journal of Zoology 77:132-138.

Hobday, A. J., and K. Evans. 2013. Detecting climate impacts with oceanic fish and fisheries data. Climatic Change 119:49-62.

Hoekstra, J. M. K. K. Bartz, M. H. Ruckelhause, J. M. Moslemi, and T. K. Harms. 2007. Quantitative threat analysis for management of an imperiled species: Chinook Salmon (Oncorhynchus tshawyts cha). Ecological Applications 17:2061-2073.

Holling, C. S. 1978. Adaptive environmental assessment and management. Wiley, Chichester, U.K.

Hollowed, A. B., M. Barange, R. J. Beamish, K. Brander, K. Cochrane, K. Drinkwater, M. G. G. Foreman, J. A. Hare, J. Holt, S. Ito, S. Kim, J. R. King, H. Loeng, B. R. Mackenzie, F. J. Mueter, T. A. Okey, M. A. Peck, V. I. Radchenko, J. C. Rice, M. J. Schirripa, A. Yatsu and Y. Yamanaka. 2013a. Projected impacts of climate change on marine fish and fisheries. ICES Journal of Marine Science 70:1023-1037.

Hollowed, A. B., E. N. Curchister, C. A. Stock, and C. I. Zhang. 2013b. Trade-offs associated with different modeling approaches for assessment of fish and shellfish responses to climate change. Climatic Change 119:111-129. 
Hughes, R. M., S. Dunham, K. G. Maas-Hebner, J. A. Yeakley, C. B. Schreck, M. Harte, N. Molina, C. C. Shock, V. W. Kaczynski, and J. Schaeffer. 2014. A review of urban water body rehabilitation and mitigation challenges and approaches: (1) rehabilitation and remediation. Fisheries 39:18-29.

Hulse, D. W., A. Branscomb, and S. G. Payne. 2004. Envisioning alternatives: using citizen guidance to map future land and water use. Ecological Applications 14:325-341.

Isaak, D. J., C. H. Luce, B. E. Rieman, D. E. Nagel, E. E. Peterson, D. L. Horan, S. Parkes, and G. L. Chandler. 2010. Effects of climate change and wildfire on stream temperatures and salmonid thermal habitat in a mountain river network. Ecological Applications 20:1350-1371.

ISAB (Independent Scientific Advisory Board). 2007. Climate change impacts on Columbia River Basin fish and wildlife. ISAB Climate Change Report ISAB 2007-2 prepared for the Northwest Power and Conservation Council, Portland, Oregon.

Jones, K. K., T. J. Cornwell, D. L. Bottom, L. A. Campbell, and S. Stein 2014. The contribution of estuary-resident life histories to the return of adult Oncorhynchus kisutch. Journal of Fish Biology 85:52-80.

Jonsson, B., and N. Jonsson. 2011. Ecology of Atlantic Salmon and Brown Trout: habitat as a template for life histories. Springer, Fish and Fisheries Series 33, New York.

Kaeriyama, M., H. Seo, H. Kudo, and M. Nagata. 2012. Perspectives on wild and hatchery salmon interactions at sea, potential climate effects on Japanese Chum Salmon, and the need for sustainable salmon fishery management reform in Japan. Environmental Biology of Fishes 94:165-177.

Kingsolver, J. G. 2009. The well-temperatured biologist. The American Naturalist 174:755-768.

Kostow, K. E., and S. J. Zhou. 2006. The effect of an introduced summer steelhead hatchery stock on the productivity of a wild winter steelhead population. Transactions of the American Fisheries Society 135:825-841.

Lassalle, G., M. Béguer, L. Beaulaton, and E. Rochard. 2008. Diadromous fish conservation plans need to consider global warming issues: an approach using biogeographical models. Biological Conservation 141:1105-1118.

Lichatowich, J. 1999. Salmon without rivers: a history of the Pacific salmon crisis. Island Press, Washington, D.C.

Lohse, K. A., D. A. Newburn, J. J. Opperman, and A. M. Merenlender 2008. Forecasting relative impacts of land use on anadromous fish habitat to guide conservation planning. Ecological Applications 18:467-482.

Maas-Hebner, K. M., and S. Dunham. 2014. Urbanization impacts on Pacific Northwest aquatic and riparian physical habitats. Pages 75-92 in J. A. Yeakley, K. G. Maas-Hebner, and R. M. Hughes, editors. Wild salmonids in the urbanizing Pacific Northwest. Springer, New York.

Macedo, D. R., R. M. Hughes, R. Ligeiro, W. R. Ferreira, M. Castro, N. T. Junqueira, D. R. O. Silva, K. R. Firmiano, P. R. Kaufmann, P. S. Pompeu, and M. Callisto. 2014. The relative influence of multiple spatial scale environmental predictors on fish and macroinvertebrate assemblage richness in cerrado ecoregion streams, Brazil. Landscape Ecology 29:1001-1016.

Martinez, P. J., P. E. Bigelow, M. A. Deleray, W. A. Fredenberg, B. S Hansen, N. J. Horner, S. K. Lehr, R. W. Schneidervin, S. A. Tolentino, and A. E. Viola. 2009. Western Lake Trout woes. Fisheries 34:424-442

Martins, E. B., S. G. Hinch, D. A. Patterson, M. J. Hague, S. J. Cooke, K. M. Miller, M. F. Lapointe, K. K. English, and A. P. Farrell. 2011. Effects of river temperature and climate warming on stockspecific survival of adult migrating Fraser River Sockeye Salmon (Oncorhynchus nerka). Global Change Biology 17:99-114

Marzin. A., P. F. M. Verdonschot, and D. Pont. 2012. The relative influence of catchment, riparian corridor, and reach-scale anthropogenic pressures on fish and macroinvertebrate assemblages in French rivers. Hydrobiologia 704:375-388.

Michael, J. H., Jr. 1998. Pacific salmon spawner escapement goals for the Skagit River watershed as determined by nutrient cycling considerations. Northwest Science 72:239-248.

Molina, N. M. 2014. Regulatory and planning approaches to protecting salmonids in an urbanizing environment. Pages 31-45 in J. A. Yeakley, K. G. Maas-Hebner, and R. M. Hughes, editors. Wild salmonids in the urbanizing Pacific Northwest. Springer, New York.

Mote, P., A. K. Snover, S. Capalbo, S. D. Eigenbrode, P. Glick, J. Littell, R. Raymondi, and S. Reeder. 2014. Northwest. Pages 487-513 in J. M. Melillo, T. C. Richmond, and G. W. Yohe, editors. Climate change impacts in the United States: the third national climate assessment. U.S. Global Change Research Program, Washington, D.C.

Muhlfeld, C. C., R. P. Kovach, L. A. Jones, R. Al-Chokhachy, M. C. Boyer, R. F. Leary, W. H. Lowe, G. Luikart, and F. W. Allendorf. 2014. Invasive hybridization in a threatened species is accelerated by climate change. Nature Climate Change 4:620-624.

Nagasaka, A., Y. Nagasaka, K. Ito, T. Mano, M. Yamanaka, A. Katayama, Y. Sato, A. I. Grankin, A. I. Zdorikov, and G. A. Boronov. 2006. Contributions of salmon-derived nitrogen to riparian vegetation in the Northwest Pacific region. Journal of Forestry Research 11:377-382

Naman, A. W., and C. S. Sharpe. 2012. Predation by hatchery yearling salmonids on wild subyearling salmonids in the freshwater environment: a review of studies, two case histories, and implications for management. Environmental Biology of Fishes 94:21-28.

Nichol, L. M., and D. M. Shackleton. 1996. Seasonal movements and foraging behaviour of northern resident killer whales (Orcinus orca) in relation to inshore distribution of salmon (Oncorhynchus spp.) in British Columbia. Canadian Journal of Zoology 74:983-991.

Nie, M. A., and C. A. Schultz. 2012. Decision-making triggers in adaptive management. Conservation Biology 26:1137-1144.

Nielsen, J. L., G. T. Ruggerone, and C. E. Zimmerman. 2013. Adaptive strategies and life history characteristics in a warming climate: salmon in the Arctic? Environmental Biology of Fishes 96:11871226 .

NMFS (National Marine Fisheries Service). 2007. Adaptive management for ESA-listed salmon and steelhead recovery: decision framework and monitoring guidance. NMFS, Northwest Region and Northwest Fisheries Science Center, Seattle.

— 2014. Draft environmental impact statement on two joint state and tribal resource management plans for Puget Sound salmon and steelhead hatchery programs. NMFS, West Coast Region, Seattle.

Oberdorff, T., C. Jezequel, M. Campero, F. Carvajal-Vallejos, J. F. Cornu, M. S. Dias, F. Duponchelle, J. A. Maldonado-Ocampo, H. Ortega, J. F. Renno, and P. A. Tedesco. 2015. Opinion paper: how vulnerable are Amazonian freshwater fishes to ongoing climate change? Journal of Applied Ichthyology 31(Supplement 4):4-9.

OCSRI (Oregon Coastal Salmon Restoration Initiative). 1997. Oregon plan for salmon and watersheds (consisting of the Oregon Coastal Salmon Restoration Initiative, March 10, 1997 and as amended with the Steelhead Supplement, December 1997). Governor's Natural Resources Office, Salem, Oregon.

ODFW (Oregon Department of Fish and Wildlife). 2010. Lower CoIumbia River conservation and recovery plan for Oregon populations of salmon and steelhead. ODFW, Salem.

- 2013. Conservation plan for fall Chinook Salmon in the Rogue species management unit. ODFW, Salem.

- 2014. Coastal multi-species conservation and management plan. ODFW, Salem.

ODFW (Oregon Department of Fish and Wildlife) and NMFS (National Marine Fisheries Service). 2011. Upper Willamette River conservation and recovery plan for Chinook Salmon and steelhead. ODFW, Salem.

Oregon Administrative Rule 635-007-0502. Native Fish Conservation Policy. Revised September 12, 2003. Oregon Fish and Wildlife Commission. Salem, Oregon.

Orr, J. C., K. Caldeira, V. Fabry, J.-P. Gattuso, P. Haugan, P. Lehodey, S. Pantoja, H.-O. Pörtner, U. Riebesell, R. Trull, M. Hood, E. Urban, and W. Broadgate. 2009. Report on research priorities for ocean acidification: second international symposium on the ocean in a high-CO world. Available: www.scor-int.org/HighCO2_World/2008-Research_Priorities.pdf. (February 2014).

Paquet, P. J., T. Flagg, A. Appleby, J. Barr, L. Blankenship, D. Campton, M. Delarm, T. Evelyn, D. Fast, J. Gislason, P. Kline, D. Maynard, L. Mobrand, G. Nandor, P. Seidel, and S. Smith. 2011. Hatcheries, conservation, and sustainable fisheries-achieving multiple goals: results of the Hatchery Scientific Review Group's Columbia River Basin review. Fisheries 36:547-561.

Parma, A., P. Amarasekare, M. Mangel, J. Moore, W. W. Murdoch, E. Noonburg, M. A. Pascual, H. P. Possingham, K. Shea, C. Wilcox, and D. Yu. 1998. What can adaptive management do for our fish, forests, food, and biodiversity? Integrative Biology 1:16-26.

Peterson, W. T., C. A. Morgan, J. O. Peterson, J. L. Fisher, B. J. Burke, and K. Fresh. 2014. Ocean ecosystem indicators of salmon marine survival in the northern California current. Northwest Fisheries Science Center, Seattle. Available: www.nwfsc.noaa.gov/ research/divisions/fe/estuarine/oeip/documents/Peterson etal_2014.pdf. (March 2016). 
Piccolo, J. J., M. D. Adkison, and F. Rue. 2009. Linking Alaskan salmon management with ecosystem-based escapement goals: a review and perspective. Fisheries 34:124-134

Punt, A. E., T. A'mar, N. A. Bond, D. S. Butterworth, C. L. de Moor, J. A. A. De Oliveira, M. A. Haltuch, A. B. Hollowed, and C. Szuwalski. 2014. Fisheries management under climate and environmental uncertainty: control rules and performance simulation. ICES Journal of Marine Science 71:2208-2220.

Quamme, D. L., and P. A. Slaney. 2003. The relationship between nutrient concentration and stream insect abundance. Pages 163176 in J. G. Stockner, editor. Nutrients in salmonid ecosystems; sustaining production and biodiversity. American Fisheries Society, Symposium 34, Bethesda, Maryland.

Raven, J., K. Caldeira, H. Elderfield, O. Hoeg-Guldberg, P. Liss, U. Riebesell, J. Shepherd, C. Turley, and A. Watson. 2005. Ocean acidification due to increasing atmospheric carbon dioxide. The Royal Society, Policy Document 12/05, London.

Reimers, P. E. 1973. The length of residence of juvenile fall Chinook in Sixes River, Oregon. Oregon Fish Commission Research Report 4(2). Oregon Fish Commission. Portland, Oregon.

Rist, L., B. M. Campbell, and P. Frost. 2012. Adaptive management: where are we now? Environmental Conservation 40:5-8.

Roni, P., K. Hanson, and T. Beechie. 2008. Global review of the physical and biological effectiveness of stream habitat rehabilitation techniques. North American Journal of Fisheries Management 28:856-890

Roth, N. E., J. D. Allan, and D. L. Erickson. 1996. Landscape influences on stream biotic integrity assessed at multiple spatial scales. Landscape Ecology 11:141-156.

Ruggerone, G. T., B. A. Agler, and J. L. Nielsen. 2012. Evidence for competition at sea between Norton Sound Chum Salmon and Asian hatchery Chum Salmon. Environmental Biology of Fishes 94:149-163

Runge, M. C. 2011. An introduction to adaptive management for threatened and endangered species. Journal of Fish and Wildlife Management 2:220-233.

Salinger, M. J. 2013. A brief introduction to the issue of climate and marine fisheries. Climate Change 119:23-35

Sály, P., P. Takács, I. Kiss, I., P. Bíró, and T. Erös. 2011. The relative influence of spatial context and catchment- and site-scale environmental factors on stream fish assemblages in a human-modified landscape. Ecology of Freshwater Fish 20:251-262.

Scheuerell, M. D., and J. G. Williams. 2005. Forecasting climateinduces changes in the survival of Snake River spring/summer Chinook Salmon (Oncorhynchus tshawytscha). Fisheries Oceanography 14:448-457.

Steel, E. A., D. W. Jensen, K. M. Burnett, K. Christiansen, J. C. Firman, B. E. Feist, K. J. Anlauf, and D. P. Larsen. 2012. Landscape characteristics and Coho Salmon (Oncorhynchus kisutch) distributions: explaining abundance versus occupancy. Canadian Journal of Fisheries and Aquatic Sciences 69:457-468.

Stockner, J. G., editor. 2003. Nutrients in salmonid ecosystems: sustaining production and biodiversity. American Fisheries Society, Symposium 34, Bethesda, Maryland.

Tatara, C. P., and B. A. Berejikian. 2012. Mechanisms influencing competition between hatchery and wild juvenile anadromous Pacific salmonids in fresh water and their relative competitive abilities. Environmental Biology of Fishes 94:7-19.

Tedesco, P. A., T. Oberdorff, J.-F. Cornu, O. Beauchard, S. Brosse, H. H. Dürr, G. Grenouillet, F. Leprieur, C. Tisseuil, R. Zaiss, and B. Hugueny. 2013. A scenario for impacts of water availability loss due to climate change on riverine fish extinction rates. Journal of Applied Ecology 50:1105-1115.

USEPA (U. S. Environmental Protection Agency). 2013. National rivers and streams assessment 2008-2009: a collaborative survey. Environmental Protection Agency, EPA/841/D-13/001, Washington, D.C.

Van Sickle, J., J. Baker, A. Herlihy, P. Bayley, S. Gregory, P. Haggerty, L. Ashkenas, and J. Li. 2004. Projecting the biological condition of streams under alternative scenarios of human land use. Ecological Applications 14:368-380.

Walters, C. 1986. Adaptive management of renewable resources. Blackburn Press, Caldwell, New Jersey.

Wang, L., J. Lyons, P. Rasmussen, P. Seelbach, T. Simon, M. Wiley, P. Kanehl, E. Baker, S. Niemela, and P. M. Stewart. 2003. Watershed, reach, and riparian influences on stream fish assemblages in the Northern Lakes and Forest Ecoregion, U.S.A. Canadian Journal of Fisheries and Aquatic Sciences 60:491-503.

Wenger, S. J., M. C. Freeman, L. A. Fowler, B. J. Freeman, and J. T. Peterson. 2010. Conservation planning for imperiled aquatic species in an urbanizing environment. Landscape and Urban Planning 97:11-21.

Williams, B. K., R. C. Szaro, and C. D. Shapiro. 2009. Adaptive management: the U.S. Department of Interior technical guide. U.S Department of the Interior, Adaptive Management Working Group, Washington, D.C.

Wipfli, M. S., J. P. Hudson, J. P. Caouette, and D. T. Chaloner. 2003. Marine subsidies in freshwater ecosystems: salmon carcasses increase growth rates of stream-resident salmonids. Transactions of the American Fisheries Society 132:371-381.

Yeakley, J. A. 2014. Urban hydrology in the Pacific Northwest. Pages 59-74 in J. A. Yeakley, K. G. Maas-Hebner, and R. M. Hughes, editors. Wild salmonids in the urbanizing Pacific Northwest. Springer, New York.

Yeakley, J. A., D. Ervin, H. Chang, E. Granek, V. Dujon, V. Shandas, and D. Brown. 2016. Ecosystem services of streams and rivers. Pages 335-352 in D. Gilvear, M. Greenwood, M. Thoms, and P. Wood, editors. River science: research and applications for the 21st century. Wiley, Hoboken, New Jersey.

Yeakley, J. A., K. G. Maas-Hebner, and R. M. Hughes. 2014. Wild salmonids in the urbanizing Pacific Northwest. Springer, New York

Zhang, J., D. Gilbert, A. J. Gooday, L. Levin, S. W. A. Naqvi, J. J. Middelburg, M. Scranton, A. Ekau, Peña, B. Dewitte, T. Oguz, P. M. S. Monteiro, E. Urban, N. N. Rabalais, V. Ittekkot, W. M. Kemp O. Ulloa, R. Elmgren, E. Escobar-Briones, and A. K. Vander Plas. 2010. Natural and human-induced hypoxia and consequences for coastal areas: synthesis and future development. Biogeosciences 7:1443-1467. AFS

\section{The World Leader \& Innovator in Fish Tags}

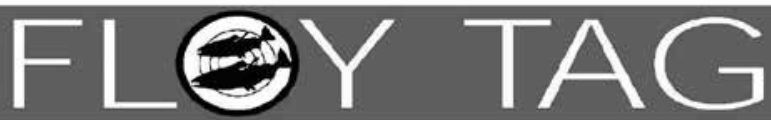

\section{Your Research Deserves the Best}
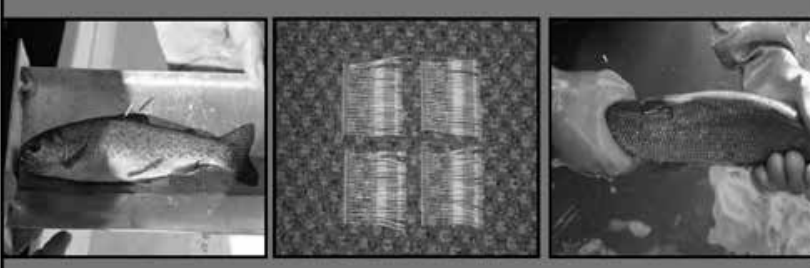

- Call 800-843-1172 to discuss your

custom tagging needs

-Email us at sales@floytag.com

- View our website for our latest catalog www.floytag.com 